\title{
The Implications of Funding on Enrolment Rates of International Postgraduate Students: The Case of Engineering Students
}

\author{
Dr. Kehdinga George Fomunyam \\ Teaching and Learning Development Center, Mangosuthu University of Technology, Durban, South Africa.
}

\begin{abstract}
In the quest for knowledge, more and more students are leaving home and venturing to other continents to earn undergraduate and postgraduate degrees. In some cases, these students bear the brunt of their fees and in other cases, these fees are subsidized or fully paid for by governments, institutions and organisations through grants, aids, student loans and scholarships. Over the years the education sector in numerous countries especially after the economic meltdown, have been experiencing budget cuts and fluctuations in government funding of higher institution programmes. Students are looking elsewhere for funds to earn their degrees. Even STEM courses, having come into focus and received attention and support lately from governments all over the world, is not left out. This paper examines the availability and accessibility of funding and its effect on international student enrolment rates in graduate engineering programmes. All types of funding and aid schemes have a positive impact on enrolment decisions of international postgraduate engineering students but funding has been insufficient to match the demand and high cost of international student's tuition which is one of the reasons for declining enrolment numbers. Government and private sector collaboration in providing better funding for postgraduate education is imperative for augmenting current funding efforts to aid prospective students in acquiring degrees both locally and internationally.
\end{abstract}

Keywords: Funding, enrolment, engineering, postgraduate, international

\section{INTRODUCTION AND PROBLEM}

Engineering has always been one of the basic building blocks of modern industrial society. It is the creative application of scientific principles and skills to design or develop structures, machines, apparatus or manufacturing processes, etc. (Britannica, 2020). Most national development discussions centres on engineering works in terms of electricity, water supply, roads, telecommunications, transportation, buildings, factories, machines and much more. Many nations are studying the trends of change and making modifications to their engineering education content in order to produce engineering graduates that can adapt to modern technological trends. Postgraduate degrees are taken for a number of different reasons, such as to move into academia and research or to specialise a career path or change track entirely and these can be acquired locally or internationally. The USA has the world's largest international student population, with more than 1,000,000 students choosing to broaden their education and life experience in the United States. According to Studee, the attraction to studying in the US is attributable to 3 principal factors a commitment to excellence, freedom of choice, and an appealing future. The US also offers a consistently high standard of education.

According to the IIE (2019), 51.6\% of international students in the US pursued STEM fields in 2018/19, an increase of 9.4\% from the previous year. Engineering remained the largest academic field for international students in 2018/19, with $21.1 \%$ of all international students. The levelling of declines in newly enrolled international students continued into the 2019/20 academic year as evidenced by data from the 2019 Fall International Student Enrolment Snapshot Survey. Data from an annual survey by the Council of Graduate Schools show a fall in applications of about $7 \%$ over the past two years, concentrated mostly at the master's-degree level. By contrast, applications to doctoral programs actually ticked upward over the same two years.

New enrollment of international students at U.S. universities declined by more than $10 \%$ between the 2015-16 and 20182019 academic years (Forbes, 2019). While applications from foreign students to American graduate schools in 2018/19 fell by $7 \%$, first-time international enrolment decreased by only $0.9 \%$ recovering from sharper declines the year before (IIE, 2019). The countries sending the most students to the United States are, in order, China, India, South Korea, Saudi Arabia, Canada, and Vietnam (Ednext,2019). Students also flock to America from some 200 other countries around the globe. But enrolment numbers are falling. Since 2016 enrolment growth has ceased and the numbers are recording a decline. Though growth has stagnated, the numbers of international students remain substantially higher than they were a decade ago (Ednext, 2020). International students make up 5.5\% of the total U.S. higher education population. According to NAFSA (2019), the more than one million international students studying at U.S. colleges and universities contributed \$39 billion to the U.S. economy and supported more than 455,622 jobs during the 2017-2018 academic year. The number grew to an all-time high in the $2018 / 19$ academic year with data from the U.S. Department of Commerce pegging the figure at $\$ 44.7$ billion, an increase of 5.5\% from the previous year (IIE, Institute of International Education, 2019). The implication of the decline is that universities are hurt financially as much needed funds in form of very high tuition costs paid by international students is lost to the universities who utilize this money to balance out the drop in government funding and keep their institutions running. Also, the U.S work force is 
International Journal of Engineering Research and Technology. ISSN 0974-3154, Volume 13, Number 7 (2020), pp. $1567-1574$

(C) International Research Publication House. https://dx.doi.org/10.37624/IJERT/13.7.2020.1567-1574

losing a pool of skilled workers needed by the companies. In 2016, the decline cost the US economy $\$ 11.8$ billion and more than 65,000 jobs (NAFSA, CNN Business, 2019). This study focuses on addressing some pertinent issues namely, what is currently obtainable in terms of funding? Why is international graduate engineering enrolment declining? How can sponsorship be made accessible to a larger number of applicants?

\section{A look at funding options for International Students}

Many U.S. higher institutions offer much more financial aid for international graduate study than undergraduate study but even this is limited. International students are usually not eligible for U.S. federal aid, however, there may be other sources of funding (Internationalstudent.com). In the United States, domestic graduate students and to an extent international graduate students are typically subsidized by the federal and state governments, universities, foundations and other sources of funding, including financial aids, funding through departments and fellowships, scholarships ranging from university scholarships to merit and financial scholarships, government and privately funded scholarships to part scholarships and fellowships from various sources. Majority of US universities have scholarship programmes, most of which are open to applications from international students. According to the Fulbright Commission, more than 600 American universities offer scholarships worth $\$ 20,000$ or more to international students. They are typically assessed on academic merit, financial need, or extracurricular contribution. In addition to these, there are a range of scholarships available from private organisations and donors, with a broad range of criteria for eligibility (THE, 2018).

Many are supported by research assistantships (RAs), with funding obtained by a principal investigator from government grants (such as from National Science Foundation, National Institutes of Health (NIH), the Department of Energy, the Department of Agriculture, the Department of Education, and the Department of Defence) and corporate contracts. Others are supported by teaching assistantships (TAs) funded by universities, with funds from state legislatures for public universities or tuition and endowment income for private universities. TAs and RAs are working at low wages, so the calculation of how much they are subsidized is further complicated. These aids and scholarships make it possible for a large number of students to earn their degrees, reduce student debt and improve performance by eliminating financial concerns that could be a source of distraction.

Local funding from student's host country are also available from the government, NGOs and corporate bodies in form of scholarships, grants and other forms of assistance. The types of funding are similar for both domestic and international graduate students, but the mix of funding is different, partly because of restrictions on access to specific funding streams. The primary support mechanism for postdoctoral scholars is the research grant. Scholarships in the form of fee waivers, bursaries or both might be offered to postgraduates. Funding numbers for postdoctoral scholars are not reported by citizenship, but restrictions limit the access of international scholars to training grants and fellowships.

\section{Factors Influencing International Student Enrolment in the US}

International students, who pay on average three times more than their domestic counterparts, provide crucial financial resources to higher education institutions and constitute the majority of graduate students in STEM courses - science, technology, engineering, and mathematics (Schulmann, 2019). In the decade prior to 2016, international enrolment rose by $60 \%$. Students flocked to the US for its relative affordability and student-friendly immigration policies back then compared to countries like the UK and Australia (Science mag, 2014).

Other factors that drove this increase include an increase in the number of Chinese families who can afford the costs of American higher education. Chinese students account for the majority of international students in the U.S with over 369,000 choosing to take courses there in the 2018/19 academic year. The authors estimate that the percentage of Chinese families who have incomes higher than the average cost of out-of-state tuition and room and board at an American public university has grown "exponentially" from less than $0.005 \%$ in 2000 to more than $2 \%$ in 2013 (NRC, 2005). Second, high school enrolment expanded in China, from 63.8 million students to 95 million between 1996 and 2012, according to United Nations Educational, Scientific and Cultural Organization figures. And third, China's own higher education capacity is comparatively small: the authors note that while China has about four times the population of the U.S, it has fewer than half the number of universities (NRC, 2005).

Another reason for the rising international enrolment of the 1990s may have been the lure of jobs in industries. Access to US jobs for foreign-born people is often much better for those who have been educated in the United States. Enrolments also may have been influenced by the increases in research assistantship funding for graduate students and postdoctoral scholars during the middle to late 1990s, led by a rapid increase in the budget of the NIH. Availability or lack of funding in form of local and foreign aids, grants and student loans also influences graduate enrollment rate.

Why the recent decline? Apart from increasing tuition cost, the drop in enrollment occurring from 2015 can be attributed to the fact that potential students are now opting to study in other countries with more flexible policies like Canada and Australia, the US has proposed or implemented policies aimed at making it more difficult for international students to remain and work in the US after graduation. Over the past two years USCIS has also denied $\mathrm{H}-1 \mathrm{~B}$ petitions at a historically high rate. Obtaining an $\mathrm{H}-1 \mathrm{~B}$ visa is typically the only practical way for an international student to work long term in the US (Forbes, 2019). With state education funding suffering cutbacks all across America, it is assumed that funds earmarked for sponsoring international students by state universities are also affected, international tuition fees are raised yearly to cover the deficit in funding, resulting in a decline in international student's enrolment. Doctoral degree earners have only slightly increased. Overall the number of international students from all over the world applying to the US to earn graduate engineering degrees is declining largely due to increased tuition cost but other factors affecting 
International Journal of Engineering Research and Technology. ISSN 0974-3154, Volume 13, Number 7 (2020), pp. $1567-1574$

(C) International Research Publication House. https://dx.doi.org/10.37624/IJERT/13.7.2020.1567-1574

enrollment include access to funding, income level, a country's immigration policy, and competition from other countries offering favourable policies to students.

\section{Declining rate of Enrolment for International Postgraduate Engineering Students}

According to a report from the National Foundation for American Policy, a research organization focused on immigration and the economy, many U.S. universities "both majors and graduate programs could not be maintained without international students." The report found that between 1995 and 2015, the number of full-time domestic students enrolled in electrical engineering decreased by $17 \%$, from 9,399 students in 1995 to 7,783 in 2015, while the number of full-time international graduate students increased by 270\%, from 8,855 to 32,736. Between 2000 and 2015, the proportion of first-time, full-time $S \& E$ international students increased. In engineering, the number of master's degrees awarded declined between 2004 and 2007, similar to bachelor's degrees, but later increased and in 2015 was the highest in the last 16 years (NSB, 2018).

About 240,000 international students on temporary visas were enrolled in $S \& E$ graduate programs in 2015, representing $36 \%$ of total U.S. graduate enrolment. After a post-9/11 decline, the numbers of first-time, full-time international graduate students enrolled increased steadily in most broad fields through 2015. Declines and subsequent increases in number were concentrated in engineering and computer sciences, the fields heavily favoured by international students.

However, since 2015 the US has recorded a steady decline in international graduate enrolment numbers. This decline has affected engineering enrolment as well and is mostly attributable to the very limited funding available to graduate engineering students to cover expensive international tuition cost. A large number of applicants have to compete for very limited funded degrees resulting in lower enrolment rates. On the flip side, an abundance of funding is directly linked to higher enrolment and completion rates. Completion rates are higher when education is subsidized and made more affordable.

More recently, data from SEVIS show an overall 6\% decline in international graduate students from fall 2016 to fall 2017. 'In 2017, 62\% of all international students in graduate programs at U.S. institutions were enrolled in S\&E fields. Between fall 2016 and fall 2017, the number of international graduate students enrolled in S\&E fields decreased in engineering (from 96,300 to 89,000). New data from the National Centre for Science and Engineering Statistics, Survey of Graduate Students and Post doctorates in Science and Engineering showed that 96,756 engineering students enrolled to earn master's degrees from the US in 2017 but fell to 93,064 in 2018 , while doctoral student numbers rose from 68,825 in 2017 to 70,237 in 2018' (NSF, 2018). In 2018/19, $51.6 \%$ of international students in the United States pursued STEM fields. Engineering remained the largest academic field for international students in $2018 / 19$ with $21.1 \%$ of all international students enrolling to study engineering. The number of students enrolling for the first time at a U.S. institution in 2018/19 declined by $0.9 \%$, recovering from sharper declines the year before. The leveling of declines in newly enrolled international students continues into the 2019/20 academic year, according to data from a survey conducted by IIE and nine partner higher education associations. Apart from high tuition cost, other factors influence the decline in international graduate enrollment in the U.S as outlined in the previous section ( Malley, UWN, 2019).

\section{Implications of Funding on Enrolment rate of International Graduate Engineering Students}

The information below shows a relationship between funding and international graduate enrollment rate by comparing enrollment rates to fluctuations in government funding at the time. Apart from private aid to students, government funds are apportioned to international students for every academic year based on limited available resources and enrolment level responds to this availability by declining or increasing for the period.

The decline is an indication of the continually rising cost of international education for which limited funding is available for foreign students. This limits the quality of education obtained by students if they have to compromise or look elsewhere to get a lesser quality of education especially for those from developing countries. This has implications for technological, structural and overall economic growth of some nations since their graduates might not get the knowledge they need to help in restructuring or upgrading their country's economy.

\section{METHODOLOGY}

Table 1 contains information on international graduate enrolment rate from the NCSES (National Centre for Science and Engineering Statistics) survey of graduate engineering students and post doctorates in the US covering the period of $2010-2018$.

To address questions raised, a systematic literature review was carried out to locate and comprehensively review research on higher education funding, enrolment, reasons for fluctuation in enrolment, related issues and suggested solutions. These literatures comprised of 36 articles and papers all published between 2002 and 2020 and contained keywords or search terms related to research questions. These search terms are funding, enrolment rate, graduate, postgraduate engineering, international. Data presented here is derived from the annual National Science Foundation/National Institutes of Health Survey of Graduate Students and Post doctorates in Science and Engineering that represents estimates of total graduate enrolment in science, engineering, and selected health fields in 12,629 graduate units (departments, research centres, degree-granting programs and health facilities) at 582 institutions in the United States and outlying areas as of fall 2007. The survey was refined in 2007 to improve reporting: new fields were added, and some fields were reclassified. Because of these changes, current-year data are presented two ways in multi-year tables; "2007new" shows the data as 
International Journal of Engineering Research and Technology. ISSN 0974-3154, Volume 13, Number 7 (2020), pp. 1567-1574

(C) International Research Publication House. https://dx.doi.org/10.37624/IJERT/13.7.2020.1567-1574

collected using the new methodology and "2007old" shows the data as it would have been collected in prior years. All rankings using 2007 data were done using the "2007new" data.

\section{FINDINGS}

Table 1-10a. Graduate students in engineering detailed fields: $2010-2018$

\begin{tabular}{|c|c|c|c|c|c|c|c|c|c|c|c|c|c|c|c|c|c|c|}
\hline$\ddot{\bar{z}}$ & స్ & 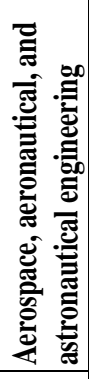 & 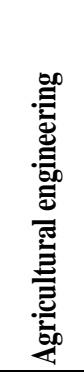 & 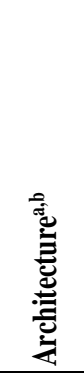 & 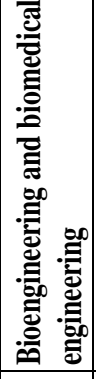 & 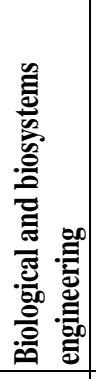 & 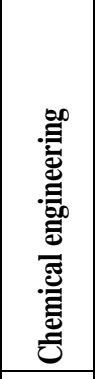 & 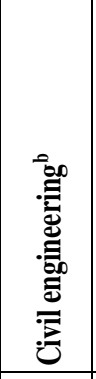 & 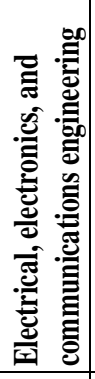 & 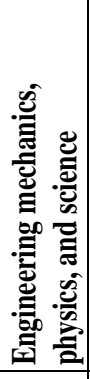 & 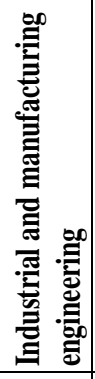 & 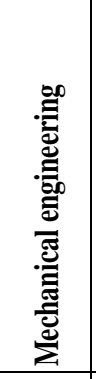 & 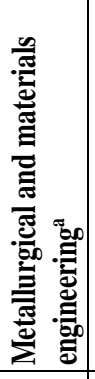 & 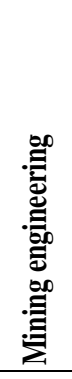 & 总 & 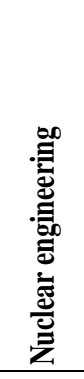 & 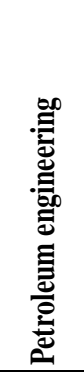 & 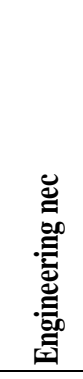 \\
\hline 2010 & 149,241 & 5,540 & 1,457 & 6,795 & 8,497 & na & 8,668 & 19,559 & 41,336 & 2,071 & 15,205 & 22,509 & 6,274 & 419 & na & 1,459 & 1,295 & 8,157 \\
\hline 2011 & 146,501 & 5,691 & 1,656 & 3,111 & 9,175 & na & $\mathbf{8 , 8 2 8}$ & 19,596 & 41,580 & 2,101 & 14,494 & 21,883 & 6,649 & 500 & na & 1,499 & 1,301 & 8,437 \\
\hline 2012 & 148,385 & 5,069 & 1,552 & 2,363 & 9,157 & na & 9,222 & 19,922 & 42,347 & 2,227 & 14,469 & 23,088 & 6,985 & 356 & na & 1,513 & 1,525 & 8,590 \\
\hline 2013 & 153,049 & 5,181 & 1,642 & 2,176 & 9,198 & na & 9,698 & 20,110 & & 2,142 & 14,363 & 24,087 & 7,144 & 357 & na & 1,459 & 1,609 & 8,321 \\
\hline 2014old & 162,013 & 5,116 & 1,717 & 1,812 & 9,510 & na & $\mathbf{9 , 8 5 3}$ & 20,660 & 50,051 & 2,151 & 14,659 & 25,508 & 7,473 & 396 & na & 1,467 & 2,056 & 9,584 \\
\hline 2014New & 164,488 & 5,116 & 1,740 & 1,817 & 9,510 & na & 9,870 & 20,789 & 51,909 & 2,162 & 14,845 & 25,651 & 7,518 & 396 & na & 1,467 & 2,056 & 9,642 \\
\hline 2015 & 169,354 & 5,345 & 1,630 & 1,565 & 9,761 & na & 10,008 & 20,978 & 52,940 & 1,708 & 16,284 & 27,314 & 7,741 & 407 & na & 1,449 & 2,021 & 10,203 \\
\hline 2016 & 168,443 & 5,416 & 1,626 & 1,671 & 10,208 & na & 10,187 & 20,569 & 50,062 & 1,756 & 16,200 & 27,898 & 8,106 & 378 & na & 1,466 & 1,862 & 11,038 \\
\hline 2017 old & 166,819 & $\mathrm{Na}$ & na & na & na & na & na & na & na & na & $\mathrm{Na}$ & na & na & na & na & na & na & na \\
\hline 2017New & 165,581 & 5,708 & 1,186 & ne & 10,882 & 234 & 10,166 & 21,132 & 47,752 & 2,136 & 15,905 & 27,428 & 6,541 & 541 & 139 & 1,442 & 1,578 & 12,811 \\
\hline 2018 & 163,301 & 5,848 & 1,032 & ne & 11,480 & 283 & 10,011 & 20,461 & 46,227 & 2,157 & 15,987 & 26,593 & 6,689 & 527 & 118 & 1,453 & 1,403 & 13,032 \\
\hline \multicolumn{19}{|l|}{$\begin{array}{l}\text { Masters } \\
\text { Students } \\
\end{array}$} \\
\hline 2017 New & 96,756 & 3,322 & 505 & ne & 4,037 & 71 & 3,292 & 13,506 & 29,816 & 679 & 12,272 & 16,279 & 2,115 & 312 & 44 & 444 & 916 & 9,146 \\
\hline 2018 & 93,064 & 3,342 & 371 & ne & 4,202 & 80 & 3,061 & 12,729 & 28,108 & 729 & 12,389 & 15,434 & 2,079 & 316 & 47 & 407 & 754 & 9,016 \\
\hline \multicolumn{19}{|l|}{$\begin{array}{l}\text { Doctoral } \\
\text { Students } \\
\end{array}$} \\
\hline $2017 \mathrm{New}$ & 68,825 & 2,386 & 681 & ne & 6,845 & & 6,874 & 7,626 & 17,936 & 1,457 & $\mathbf{3 , 6 3 3}$ & 11,149 & 4,426 & 229 & 95 & 998 & 662 & 3,665 \\
\hline 2018 & 70,237 & 2,506 & 661 & ne & 7,278 & & 6,950 & 7,732 & 18,119 & 1,428 & 3,598 & 11,159 & 4,610 & 211 & 71 & 1,046 & 649 & 4,016 \\
\hline
\end{tabular}

na $=$ not applicable; data were not collected at this level of detail in the year shown. NA = not available; nanotechnology was not collected until 2007. ne = not eligible.

nec $=$ not elsewhere classified.

NOTES: Master's and doctoral students were not reported separately until 2017.

SOURCE: National Center for Science and Engineering Statistics, Survey of Graduate Students and Post doctorates in Science and Engineering. 
International Journal of Engineering Research and Technology. ISSN 0974-3154, Volume 13, Number 7 (2020), pp. 1567-1574

(C) International Research Publication House. https://dx.doi.org/10.37624/IJERT/13.7.2020.1567-1574

\section{Federal and State Higher Education Spending Over a Ten-Year Period}

Trends in major expenditure categories, academic years 2007-17, adjusted for inflation

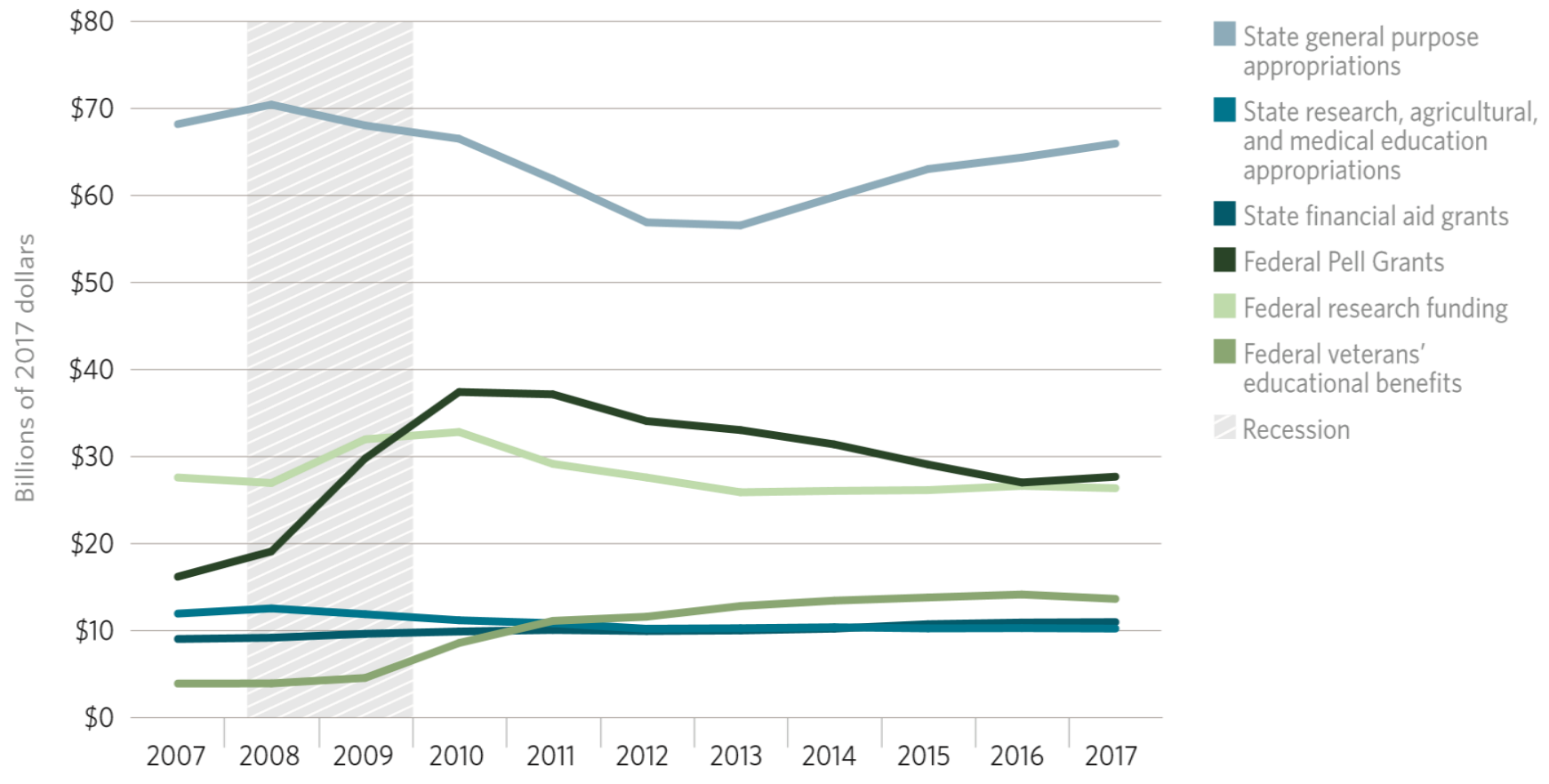

Note: Data include spending for public, nonprofit, and for-profit higher education institutions and their students, excluding loans and tax expenditures.

Sources: Pew's analysis of data from the U.S. Department of Education, "State Funding History Tables, ” fiscal years $2007-17$.

Funding granted by universities in the US to international students to subsidize tuition cost is apportioned from same funds allocated by federal and state governments, so what is the implication of an increase in federal funding and a cut in state funding of higher education institutions for international enrolment? The table shows a small increase in doctoral enrolment numbers but a decline in graduate enrolment in engineering at the master's level from 2015 which can be linked to declining higher education funding for states according to NCES data and other data sources. Authors cite data from the State Higher Education Executive Officers showing a decline in total state appropriations from $\$ 89.7$ billion in the 2007-8 academic year to $\$ 74.8$ billion in 2011 12. Between 2015-2018 state funding declined by more than $20 \%$, while federal funding increased, and master's enrolment numbers fell by 76,290 . State funding per full-time equivalent student has fallen from about $\$ 12,000$ in the mid-1980s to less than $\$ 7,000$ (Redden, 2017). First, the decline began from an enrolment peak that followed the atypical economic conditions of the late 1990s and was exacerbated by the 2008 financial crisis which dropped enrollment during the 20102012 period by 856 from 149,241 - 148,385. Enrolment picked up between 2013-2015, going from 153,049-169,354. It again declined between 2016-2018 from 168,000 - 93,000. Nearly every state cut funding to public colleges and universities since the 2008 financial crisis. This suggests a link between funding and enrolment and infers that as state funding falls, so does enrolment as HEIs apportion funds to international students from available resources. So by implication increased but limited federal funds and declining state funds leads to increase in tuition paid by universities to cover domestic students running cost, according to Urban.org (2020).

From the graph above, between 2010 - 2012 state spending was steady at around $\$ 10$ billion apart from general purpose appropriation which fell from $\$ 70$ billion to just above $\$ 55$ billion while federal spending was on the rise apart from research funding which fell slightly, the effect on enrollment was a fall from 149,000 to 146,000 then levelling at 148,000 over the 3-year period. From 2013-2015, state spending was again constant at around $\$ 10$ billion apart from general purpose appropriation which increased from below $\$ 60$ billion to around $\$ 65$ billion dollars, while federal spending held steady apart from grants which fell from around $\$ 35$ billion to below $\$ 30$ billion. The implication for education was an increase in enrollment from 153, 000- 169,000 over the period. From 2016-2017, state spending was again constant at $\$ 10$ billion with a slight increase in general appropriation while federal spending was almost constant between $\$ 10.5$ $\$ 25$ billion. In 2018 the U.S spent $1.3 \%$ of its GDP on higher education. Enrollment numbers within this period 2016-2018 fell sharply from 168,000 - 93,000 at master's level but rose slightly from 68,000 - 70, 000 at doctoral level. 
In summary, even though federal funding and federal and state spending is on the rise, the combined effect of declining state funding, increased tuition and limited aid for international students is causing a drop in graduate engineering enrollment at masters level and only a slight increase in doctoral enrollment. Higher education spending in the US at both federal and state level have been constant or rising since 2016. The exact proportion of these funds channelled towards funding international graduate engineering education is unknown but the implication of this increased funding on enrolment rate is a decline in engineering enrolment at the master's level and a slight increase in doctorate degree enrolment as a result of increase in international tuition which increases available funds and explains the increase in state higher education spending while enrollment numbers drop. When federal government makes cutbacks to state and local higher education allocation, universities make up the deficit by increasing tuition of international students as pointed out by this literature; 'The proportion of university revenues coming from tuition (as opposed to state appropriations) has risen accordingly' (Redden, 2017). This increase in tuition contributes to declining international enrolment numbers fuelled by limited funding available to students. In the U.S, State funding has mostly held steady in the last few years while federal funding has seen a decline from 2012 but has been constant since 2016.

Tuition alone grew from $19 \%$ of higher education expenditures in 1977 to $31 \%$ in 2017 . Tuition as a percentage of higher education spending grew in part because state direct appropriations per student declined. That is, state and local spending on higher education increased over the period in large part because tuition payments increased. This negatively affects international graduate engineering enrollment. Some institutions make up their limited funds by wooing international students who can afford the tuition cost and, in this way, make some money to stay afloat. It is difficult to get consistent information on private funding for students from corporations, NGOs, and home country government funding inform of grants and scholarships over time. it is assumed to have a similar effect on international graduate engineering enrolment as US government funding. The combined factors of a reduction in U.S higher education state funding, the consequent increase in international tuition, increased federal and state spending on higher education in the U.S and limited available funding for students both in their home countries and abroad all serve to drive down international enrolment rate for engineering students.

The federal government provides financial assistance mostly to individual students and funds specific research projects, while states typically support the general operations of public institutions, with smaller amounts directed toward research and financial aid. U.S. department of Education shows that inflation-adjusted government spending on higher education increased by $23 \%$ from 2008 to 2016, hitting a record high of $\$ 183$ billion in 2016. On a per-student basis in the same period, this spending increased by $16 \%$ reaching an all-time high of more than $\$ 9,000$ per student. Adjusted for inflation, states spent $\$ 5.7$ billion less on public higher education in
2017 than in 2008 (FEE, 2018). In 2017, state and local governments spent $\$ 297$ billion, or $10 \%$ of state and local direct general spending, on higher education. Higher education charges as a share of total higher education spending grew from $30 \%$ in 1977 to $40 \%$ in 2017. While federal spending to universities increased, state spending on higher education nationwide fell $\$ 1,448$ per student, or $16 \%$, after adjusting for inflation.

\section{CONCLUSION}

The enrolment rate for international engineering students at master's level, prior to 2015 was fluctuating as revealed by the NCSES table but is now on a slow but steady decline. Fewer foreign graduates are applying to the US to earn a master's degree while doctoral applicants are barely holding steady. This is attributable to limited funding from the student's country of origin and at the proposed tertiary institution as most schools have to adjust to cutbacks from the government in tertiary institutions allocation mostly at state level. Most universities have to make up for these cutbacks by increasing tuition fees for foreign students which makes earning an international engineering degree even more inaccessible to applicants who cannot find sponsors. Scholarships, loans and grants handed out by private organisations and NGOs are inadequate compared to the large number of potential applicants. In light of this, this study proposes the establishment of a joint funding scheme by the federal, state government, universities and private bodies to provide grants and scholarships to suitably qualified applicants in their quest to earn international graduate degrees which will be beneficial in reviving the economies of developing countries.

\section{CONTRIBUTION OF NEW KNOWLEDGE}

A new funding approach is needed for students from poorer countries seeking to acquire western education, the cost of which is often quite high and well beyond their means. This paper proposes that larger insurance companies in collaboration with the government set up student aid packages like grants and loan programs where students over time pay a certain amount into an account which the company matches and tops off with the added option of a lump sum student loan to be repaid over time upon completion of the study programme.

Private companies also have a role to play in adopting a more inclusive approach to providing financial support to students. Educational funding should be viewed as a key aspect of their Corporate Social Responsibility and should be implemented by setting up or expanding educational grants, scholarships and aids geared towards funding degree programmes home and abroad upon meeting fair qualification criteria. An incentive for the companies should be a tax rebate offered by the government where a percentage of the company income tax is written off in lieu of the funding scheme. Also students adopting the online learning route should explore Virtual leaning environments (VLE) such as Blackboard, Canvas, and Renweb that optimise online learning. Earning 
International Journal of Engineering Research and Technology. ISSN 0974-3154, Volume 13, Number 7 (2020), pp. 1567-1574

(C) International Research Publication House. https://dx.doi.org/10.37624/IJERT/13.7.2020.1567-1574

international degrees online is a widely popular trend and is far more affordable than on-site education as it eliminates accommodation, transportation, feeding and numerous other costs one would have to pay otherwise.

\section{REFERENCES}

Anderson, S. (2019) International student enrolment in the US has fallen $10 \%$ since 2015 . Retrieved from: https://www.forbes.com/sites/stuartanderson/2019/11/19/ne $\mathrm{w}$ international student enrolment in the US has fallen $10 \%$ since 2015

Britannica (2020) Engineering. Retrieved from: https://www.britannica.com/technology /engineering

Ednext (2020) Has President Trump Scared Away All the Foreign Students? retrieved from:

https://www.educationnext.org/has-president-trump-scaredaway-foreign-students-facts-behind-fears-higher-educationrevenue-recession/

Ebmer, W., Wirz, R. (2002). Public Funding and Enrolment into Higher Education in Europe. Retrieved from: https://www.researchgate.net/publication/5141461_Public_ Funding_and_Enrolment_into_Higher_Education_in_Europ e?enrichId=rgreq-82a335348c5746f19d69cfb694851943XXX\&enrichSource=Y292ZXJQYWdlOzUxNDE0NjE7Q VM6MTAxNTEyOTc4MTA4NDIzQDE0MDEyMTM5OD g1MTE\%3D\&el=1_x_3\&_esc=publicationCoverPdf

Foundation for Economic Education (2018). Government Spending on Education Is Higher than Ever. And for What? retrieved from: https://fee.org/articles/governmentspending-on-education-is-higher-than-ever-and-for-what/j

IIE (2019). Number of International Students in the United States Hits All-Time High. Retrieved from:

https://www.iie.org/Why-

IIE/Announcements/2019/11/Number-of-International-

Students-in-the-United-States-Hits-All-Time-High

InternationalStudent.com (2020). Study in the USA.

Retrieved from:

https://www.internationalstudent.com/study_usa/

Juris, K., Lucija, K., Sandra, E. (2006). Funding Systems and their Effect on Higher Education Systems. Country Study -Latvia.

Ing, W., Bhardwa, S. (2018) Scholarships available in the US for international students. retrieved from: https://www.timeshighereducation.com/student/advice/scho larships-available-us-international-students

Internationalstudent.com. Sources of Financial Aid.

Retrieved

from:https://www.internationalstudent.com/study_usa/finan cing/sources/

Institute of International Education (2019) Number of
International Students in the United States Hits All-Time

High. Retrieved from: https://www.iie.org/Why-

IIE/Announcements/2019/11/Number-of-International-

Students-in-the-United-States-Hits-All-Time-High

Leachman, M.M., Masterson, K. (2017). A Lost Decade in Higher Education Funding Retrieved from:

https://www.cbpp.org/research/state-budget-andtax/unkept-promises-state-cuts-to-higher-educationthreaten-access-and

Malley, B. University World News (2019). Total international student enrolment continues to fall. retrieved from: https://www.universityworldnews.com/postmobile.php?story $=20191119090641765$

National Research Council (US) Committee on Policy Implications of International Graduate Students and Postdoctoral Scholars in the United States. Policy Implications of International Graduate Students and Postdoctoral Scholars in the United States. (2005). Retrieved from: Policy Implications of International Graduate Students and Postdoctoral Scholars in the United States.

National Center for Science and Engineering Statistics (2007). Survey of Graduate Students and Post doctorates in Science and Engineering.

National Center for Educations Statistics (2018). Federal on-budget funds for education, by level/educational purpose, agency, and program: Selected fiscal years, 1970 through 2018. Retrieved from:

https://nces.ed.gov/programs/digest/d18/tables/dt18_401.30 .asp?current=yes

NAFSA: Association of International Educators. (2019). New NAFSA Data: Despite Stagnant Enrolment, International Students Contribute Nearly \$41 Billion to the U.S. Economy. Retrieved from:

https://www.prnewswire.com/news-releases/new-nafsadata-despite-stagnant-enrolment-international-studentscontribute-nearly-41-billion-to-the-us-economy300959698.html

National Science Foundation (2018). Science and Engineering Indicators 2018. Retrieved from: nsf.gov/statistics/2018/nsb2018/report/sections/highereducation-in-science-and-engineering/graduate-educationenrollment-and-degrees-in-the-united-states

National Science Foundation (2018). Survey of Graduate Students and Post doctorates in Science and Engineering, Fall 2018. Retrieved from:

https://ncsesdata.nsf.gov/gradpostdoc/2018/

Nedlund, E. (2019). The US Economy is losing billions of dollars because foreign students aren't enrolling. Retrieved from:

https://edition.cnn.com/2019/11/19/business/international students decline/index.html 
International Journal of Engineering Research and Technology. ISSN 0974-3154, Volume 13, Number 7 (2020), pp. 1567-1574

(C) International Research Publication House. https://dx.doi.org/10.37624/IJERT/13.7.2020.1567-1574

Office for Students. (2020). The effect of postgraduate loans. Retrieved from:

https://www.officeforstudents.org.uk/data-and-analysis/theeffect-of-postgraduate-loans/educational-disadvantage/

Policy Implications of International Graduate Students and Postdoctoral Scholars in the United States. Retrieved from: https://www.ncbi.nlm.nih.gov/books/NBK37566/

Postgrad.com (2020). How Can You Fund Your Postgraduate Program in The United States? retrieved from: https://www.postgrad.com/study-in-usa/fees-andfunding/funding-your-postgraduate-program-in-america/

Pewtrusts.org (2019). Two Decades of Change in Federal and State Higher Education Funding. retrieved from: https://www.pewtrusts.org/en/research-and-analysis/issuebriefs/2019/10/two-decades-of-change-in-federal-and-statehigher-education-funding

Redden, E (2017). State Shortfalls and Foreign Students. Retrieved from:

https://www.insidehighered.com/news/2017/01/03/studylooks-link-between-international-enrolment-increases-andstate-appropriation

Redden, E (2017). Inside Higher Ed. Foreign Students and Graduate STEM Enrolment. Retrieved from: https://www.insidehighered.com/quicktakes/2017/10/11/for eign-students-and-graduate-stem-enrolment

Ruzicka, A. (2018). 5 Ways to fund your studies. Retrieved from: https://city-press.news24.com/Personal-Finance/5ways-to-fund-your-studies-20181116

Studee (2020). Why is the US the most popular study abroad country? Retrieved from: studee.com/guides/why the usa is the most popular study abroad country/

Textor, C. (2018). Statistica. Number of Chinese Students that Study in the U.S.

Retrieved from: https://www.statista.com/statistics/372900/number-ofchinese-students-that-study-in-the-us/

Frostick, Tom. (2013). Disadvantaged postgraduates: who are they and how can we help them? Retrieved from: https://www.theguardian.com/higher-educationnetwork/blog/2013/jul/15/postgraduate-funding-supportdisadvantaged-students\#maincontent

TheBestSchools.org (2020) Current Trends in Education. Retrieved from:

https://thebestschools.org/magazine/current-trends-onlineeducation/

Urban.org. (2020). State and Local Finance Initiative. Retrieved from: https://www.urban.org/policycenters/cross-center-initiatives/state-and-local-financeinitiative/state-and-local-backgrounders/higher-educationexpenditures
Schulmann, P. (2019). International student tuition and the funding crisis to come.

Retrieved from:

https://www.universityworldnews.com/post-

mobile.php?story $=20190121080047664$

Science mag (2014) Why do Chinese and Indian Students come to US universities? Retrieved from: https://www.sciencemag.org/news/2014/11/datacheck why do Chinese and Indian students come to US universities

The Washington Post (2019). U.S. graduate students in STEM are mostly foreign. Retrieved from: https://www.washingtonpost.com/opinions/us-graduatestudents-in-stem-are-mostly-foreign/2019/09/25/65b28098de37-11e9-be7f-4cc85017c36f_story.html

What Is A Postgraduate Degree? A Definition. Retrieved from: https://www.postgrad.com/advice/postgraduatestudies/what-is-a-postgraduate-degree/

2018 Indicators Report. Graduate Education, Enrolment, and Degrees in the United StatesPostgrad.com (2018) https://nsf.gov/statistics/2018/nsb20181/report/sections/high er-education-in-science-and-engineering/graduateeducation-enrolment-and-degrees-in-the-united-states 